\title{
PERANGKAT LUNAK PENDUKUNG KEPUTUSAN ANALISIS PENGELOLAAN KUALITAS DAN PENGENDALIAN PENCEMARAN AIR SUNGAI
}

\author{
Toban Tiku Pairunan ${ }^{1)}$ \\ ${ }^{1)}$ Program Studi Teknik Elektro Politeknik Negeri Manado; email : topan.s.nacom71@ gmail.com
}

\begin{abstract}
ABSTRAK
Penelitian ini bertujuan merancang dan membangun suatu perangkat lunak Pendukung Keputusan Analisis Pengelolaan Kualitas dan Pengendalian Pencemaran Air Sungai. Menentukan status pencemaran dengan menggunakan model indeks pencemaran (metode storet) dan Analisis prediksi status pencemaran pada masa yang akan datang dengan menggunakan model rata-rata bergerak (Moving average). Perangkat lunak yang dirancang menggunakan MySQL dan MySQL Front sebagai database dan delphy 7 sebagai bahasa pemprograman. Hasil rancangan ini kemudian diimplementasikan pada data parameter sungai saddang di propinsi Sulawesi selatan di Badan Lingkungan Hidup Daerah (BLHD) dalam periode pemantauan tahun 2010. Hasil analisis menunjukkan rancangan perangkat lunak dapat digunakan sebagai alat bantu analisis pengelolaaan kualitas dan pengendalian air sungai. Perangkat Lunak dapat menampilkan hasil analisis storet setiap titik ukur dan seluruh titik ukur sungai. Perangkat lunak dapat melakukan proses prediksi untuk status sungai pada masa yang akan dating. Perangkat lunak mampu membuat laporan hasil analisis setiap titik ukur dan seluruh titik ukur dan perangkat lunak dapat mengidentifikasi parameter yang memiliki nilai konsentrasi tinggi, sedang dan memenuhi baku mutu sesuai dengan ketentuan standar menurut Permen KLH No.115 Tahun 2003 dan Peraturan pemerintah No.82 Tahun 2001. Berdasarkan hasil implementasil perangkat lunak, yang telah diuji coba melalui data pemantauan sungai saddang periode tahun 2010, dihasilkan nilai storet rata-rata titik ukur sebesar -64,4 dengan status sungai cemar berat.
\end{abstract}

Kata Kunci: Kualitas Air Sungai, Metode Storet, Perangkat Lunak, Rata-rata Bergerak.

\section{THE SOFTWARE TO SUPPORT THE DECISION ANALYSIS OF QUALITY MANAGEMENT AND RIVER POLLUTION CONTROL}

\begin{abstract}
The study aims to design and establish software to support the decision of quality management and river pollution control. The System is analysed by means of pollution indeks model (storet Method) to determine pollution status and the average moving model (Moving Average) in order to predict pollution status in the future. The software was designed using MySQL and the MySQL font and Delphy 7 as the programming language. The outcome was implemented on the data parameter of saddang River in south Sulawesi Province, at Regional Environmental Agency (BLHD) for the monitoring period of 2010.The analysis indicates that the design can be used as an analysis tool for quality management and water control of the river. The software is capable of displaying the result of storet analysis of every measured point of the whole points of the river. It can perform storet value predict the river pollution status in the future. It is also capable of identifying the parameter having the highest concentration value, the middle one, and the fulfilling the standard quality according to the rules of environmental minister No.115 of 2003 and the government regulation No.82 of 2001 . The average Storet value of the measured point is 64.4 with a status of heavily polluted.
\end{abstract}

Keywords: Quality River Water, Storet Method, Software, Moving Average

\section{PENDAHULUAN}

Perkembangan Suatu daerah memacu terjadinya pencemaran lingkungan baik pencemaran air, tanah dan udara. Sungai merupakan tempat akumulasi pembuangan limbah dari berbagai kegiatan manusia, 
sebelum akhirnya dialirkan ke danau atau laut. Kondisi ini akan mengakibatkan semua bahan pencemar yang terlarut dalam bentuk limbah cair dan padat akan masuk kedalam aliran sungai. Besarnya bahan pencemar yang masuk ke sungai akan berpengaruh terhadap kualitas air sungai. Pada titik tertentu akan mengakibatkan terjadinya pencemaran

Salah satu upaya untuk memantau dan mengendalikan pencemaran air sungai adalah melakukan pengukuran dan analisis kualitas air sungai, sebagaimana diatur dalam Peraturan Pemerintah no 82 tahun 2001. Untuk menganalisis kualitas air sungai diperlukan perangkat alat pendukung, baik perangkat keras (hardware) maupun perangkat lunak (software).

Permasalahan yang dijumpai oleh peneliti dalam sistim pengelolaan dan pengendalian air sungai oleh Badan lingkungan hidup daerah (BLHD) propinsi sulawesi selatan adalah belum adanya suatu perangkat lunak pendukung keputusan dan analisis pengelolaan kualitas air sungai yang dapat digunakan sebagai perangkat untuk pengambilan keputusan secara efektif . Hal ini pula diakui oleh staff Badan Lingkungan Hidup Daerah (BLHD) belum ada perangkat lunak basis data dan analisis yang terintegrasi digunakan dalam pengelolaan kualitas dan pengendalian pencemaran air sungai. Untuk itu penelitian mengenai bagaimana membangun perangkat alat bantu pengelolaan kualitas air sungai khususnya untuk memantau dan mengendalikan kualitas air sungai sangat penting.

Berdasarkan permasalahanpermasalahan yang peneliti jumpai dan melihat betapa pentingnya sistim pemantauan dan analisis pengelolaan kualitas dan pengendalian air sungai, maka diperlukan instrument analisis yang dapat menggali secara rinci dan utuh gambaran kualitas dan pengendalian pencemaran air sungai, sehingga muncul sebuah ide dan pemikiran untuk mengimplementasikan masalah ini ke dalam sebuah sistim. Sistim ini dapat menjadi perangkat lunak yang dapat mengolah data parameter-parameter kualitas air sungai menjadi informasi. Perangkat ini akan mampu menyajikan hasil analisis tentang keadaan kualitas air sungai yang diakibatkan oleh konsentrasi limbah dari berbagai aktivitas yang dilakukan oleh penduduk antara lain dari pemukiman,pertanian dan industri, selain itu perangkat ini pula dapat melakukan prediksi kedepan keadaan konsentrasi buangan limbah pada titik-titik pengukuran dengan menggunakan model analisis matematis (statistic).

\section{TINJAUAN PUSTAKA}

\section{Sistem Pendukung Keputusan(Decision Support System)}

Sistem pendukung keputusan (Decision support system) merupakan sistem informasi interaktif yang menyediakan informasi, pemodelan dan pemanipulasian data. Konsep system pendukung keputusan (SPK) pertama kali diungkapkan pada tahun 1970-an oleh Michael S. Scoot Morton dengan istilah Manajement Decision System. Selanjutnya, sejumlah perusahaan lembaga penelitian dan perguruan tinggi mulai melakukan penelitian dan membangun SPK

Menurut Turban, SPK terdiri atas tiga komponen utama dan satu komponen pilihan atau sub system, terdiri dari: 1) Data management; 2) Model management; 3) Communication (dialog sub system); dan 4) Knowledge Management (Turban, 1995; Upper, 2001).

\section{Sistim Peramalan (Forecasting System)}

\begin{tabular}{ccr}
\multicolumn{2}{c}{ Peramalan } & (Forecasting) \\
diartikan sebagai & kegiatan & untuk
\end{tabular} memprediksi dan memperkirakan kondisi masa depan dengan berdasarkan data-data tertentu. Metode peramalan dapat diklasifikasikan menjadi dua kategori, yaitu Kualitatif dan Kuantitatif. Metode kualitatif ini merupakan metode untuk melakukan forecast tetapi tanpa data-data historis (Walpole, 1995).

Metode peramalan yang menggunakan data masa lalu salah satunya adalah metode time series (Metode moving average). Secara aljabar, rata-rata bergerak tunggal dapat dituliskan sebagai berikut.

$$
\begin{aligned}
& F_{T+1}=\frac{X_{1}+X_{2}+\ldots+X_{T}}{T}=\frac{1}{T} \sum_{i=1}^{T} X_{i} \\
& F_{T+2}=\frac{X_{2}+\ldots+X_{T}+X_{T+1}}{T}=\frac{1}{T} \sum_{n=1}^{T+1} X_{i}
\end{aligned}
$$

Keterangan :

$\mathrm{F}_{T+1} \quad$ : peramalan untuk periode ke $\mathrm{T}+1$ 
$\mathrm{X}_{T} \quad$ : data pada periode $\mathrm{T}$

$\mathrm{T}$ : jangka waktu perataan

$\mathrm{F}_{T+2}$ : peramalan untuk periode ke $\mathrm{T}+2$

Dengan membandingkan $\mathrm{F}_{\mathrm{T}+1}$ dan $\mathrm{F}_{\mathrm{T}+2}$, dapat dilihat bahwa $\mathrm{F}_{\mathrm{T}+2}$ perlu menghilangkan nilai $\mathrm{X} 1$ dan menambah nilai $\mathrm{X}_{\mathrm{T}+1}$, begitu nilai ini tersedia. Metode rata-rata bergerak tunggal ini biasanya lebih cocok digunakan untuk melakukan peramalan hal-hal yang bersifat random, artinya tidak ada gejala trend naik maupun turun, musiman, dan sebagainya, melainkan sulit diketahui polanya (Walpole, 1995).

\section{Analisis Data}

\section{Metode Perhitungan indeks pencemaran (Metode storet)}

Metode STORET merupakan salah satu metode untuk menentukan status mutu air yang umum digunakan. Secara prinsip metode STORET adalah membandingkan antara data kualitas air dengan baku mutu air yang disesuaikan dengan peruntukannya guna menentukan status mutu air. Cara untuk menentukan status mutu air adalah dengan menggunakan sistem nilai dari "US - EPA (Environmental Protection Agency) dengan mengklasifikasikan mutu air dalam empat kelas.

\section{Klasifikasi Mutu Air}

1. Kelas A: Baik sekali, skor $=0$--$\rightarrow$ Memenuhi baku mutu

2. Kelas B : Baik, skor $=-1 \mathrm{~s} / \mathrm{d}-10$ $\rightarrow$ cemar ringan

3. Kelas C: Sedang, skor $=-11 \mathrm{~s} / \mathrm{d}-30-$ $\rightarrow$ cemar sedang

4. Kelas D: Buruk, skor >=-31$\rightarrow$ Cemar berat (Anonim, 2009)

\section{Penentuan status mutu air}

Penentuan status mutu air dengan menggunakan metode STORET dilakukan dengan langkah-langkah sebagai berikut (Anonim, 2009):

1. Lakukan pengumpulan data kualitas air secara periodik sehingga membentuk data dari waktu ke waktu (time series data).

2. Bandingkan data hasil pengukuran dari masing-masing parameter air dengan nilai baku mutu yang sesuai dengan kelas air.
3. Jika hasil pengukuran memenuhi nilai baku mutu air (hasil pengukuran < baku mutu) maka diberi skor 0 .

4. Jika hasil pengukuran tidak memenuhi nilai baku mutu air (hasil pengukuran > baku mutu), maka diberi skor seperti table 1 .

Tabel 1. Pemberian sistem nilai untuk menentukan status mutu air.

\begin{tabular}{|c|c|c|c|c|}
\hline \multirow{2}{*}{$\begin{array}{l}\text { Jumiah } \\
\text { Contoh? }\end{array}$} & \multirow{2}{*}{ Nilai } & \multicolumn{3}{|c|}{ Parameter } \\
\hline & & Fisika & Kamia & Biblog \\
\hline \multirow[t]{3}{*}{$<10$} & Maksimum & .1 & 2 & 3 \\
\hline & Minimum & +1 & 2 & 3 \\
\hline & Rata-rata & 3 & -6 & -9 \\
\hline \multirow[t]{3}{*}{$\geq 10$} & Maksimum & 2 & 4 & -6 \\
\hline & Minimum & 2 & 4 & -6 \\
\hline & Rata-rata & -6 & -12 & .18 \\
\hline
\end{tabular}

Sumber: Lampiran Keputusan Menteri Negara Lingkungan Hidup Nomor 115 Tahun 2003

5. Jumlah negatif dari seluruh parameter dihitung dan ditentukan status mutunya dari jumlah skor yang didapat dengan menggunakan sistem ini.

\section{Proses - Proses Perangkat Lunak}

\section{Model Proses Perangkat Lunak}

Proses perangkat lunak adalah serangkaian kegiatan dan hasil yang berhubungan dengannya, yang menuju pada dihasilkannya produk perangkat lunak. Kegiatan ini bisa mencakup pengembangan perangkat lunak mulai dari awal, walaupun kenyataannya makin sering terjadi bahwa perangkat lunak yang baru dikembangkan dengan memperluas dan memodifikasi sistem yang telah ada.

Walaupun ada banyak proses perangkat lunak, ada kegiatan-kegiatan mendasar yang umum bagi semua proses perangkat lunak. Menurut Pressman, 1997, kegiatan-kegiatan tersebut adalah:

1. Penspesifikasian perangkat lunak. Fungsionalitas perangkat lunak dan batasan operasinya harus didefinisikan.

2. Perancangan dan implementasi perangkat lunak. Perangkat lunak yang memenuhi persyaratan harus dibuat.

3. Pemvalidasian perangkat lunak. Perangkat lunak tersebut harus divalidasi untuk menjamin bahwa perangkat lunak 
bekerja sesuai dengan apa yang diinginkan pelanggan.

4. Pengevolusian perangkat lunak. Perangkat lunak harus dapat berkembang untuk menghadapi kebutuhan pelanggan yang berubah.

\section{Model Air Terjun (Water Fall Model)}

Model pertama yang diterbitkan untuk proses pengembangan perangkat lunak diambil dari proses rekayasa lain. Model ini diilustrasikan seperti pada gambar 1 . Berkat penurunan dari satu fase ke fase lainnya, model ini dikenal sebagai 'Model Air Terjun' atau siklus hidup perangkat lunak (Sommervikke, 2003). Tahapan tahapan utama dari model ini memetakan kegiatankegiatan pengembangan dasar yaitu:

1. Analisis dan definisi persyaratan,

2. Perancangan sistem dan perangkat lunak,

3. Implementasi dan pengujian unit.

4. Integrasi dan pengujian sistem.

5. Operasi dan pemeliharaan.

Pada gambar 1 berikut memperlihatkan siklus hidup perangkat lunak

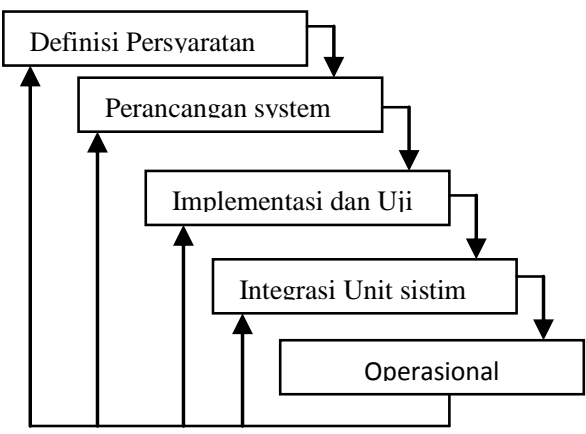

Ian Sommerville, 2003:43

Gambar 1. Model Siklus Hidup Perangkat Lunak

Pada prinsipnya hasil dari setiap fase merupakan satu atau lebih dokumen yang disetujui (ditandatangani) fase berikutnya tidak boleh dimulai sebelum fase sebelumnya selesai.

\section{METODOLOGI PENELITIAN}

Metode yang digunakan dalam penelitian ini meliputi:

1. Tahap pertama pengumpulan data pemantauan dan pengukuran dari Badan Lingkungan Hidup Daerah (BLHD), dan pengumpulan data standart yang dikeluarkan oleh kementrian Lingkungan hidup yang digunakan oleh Pemerintah daerah dimana Lokasi penelitian dilakukan.

2. Tahap kedua melakukan analisis dan perancangan perangkat lunak yang dilakukan dengan sub tahapan sebagai berikut:

a. Membuat diagram aliran data (konteks Diagram) sampai dengan level tingkat satu dengan perangkat lunak visible analisis.

b. Membuat Diagram hubungan Entitas (ERD) dengan perangkat lunak visible analisis.

c. Membuat Perancangan database dengan perangkat lunak MySQL,MYSql Front.

d. Membuat antarmuka (Interface) sub program dengan perangkat lunak Delphi.

3. Tahap Ketiga melakukan implementasi sistem perangkat lunak dengan menginput data pengukuran dari lapangan.

4. Tahap keempat melakukan pengujian perangkat lunak yang telah dibuat.

5. Tahap kelima melakukan pembuatan laporan berdasarkan hasil yang telah diperoleh dari perangkat lunak yang dibuat.

\section{HASIL DAN PEMBAHASAN}

\section{Perancangan Sistim}

Diagram system informasi perancangan perangkat lunak pendukung keputusan analisis pengelolaan kualitas dan pengendalian pencemaran air sungai adalah seperti pada gambar 2.

1. Data Standar SNI

Data SNI atau data Standart Nasional Indonesia diperoleh dari hasil keputusan menteri lingkungan hidup untuk digunakan oleh masing-masing pemerintah daerah, selanjutnya Pemda melakukan penyesuaian sesuai dengan kondisi daerah atu propinsi, dan dibuat dalam bentuk Perda. Pada system pendukung keputusan ini yang dikategorikan sebagai data SNI adalah:

- Data standar parameter Kimia

- Data standar parameter Biologi

- Data standar parameter Fisika

Ketiga data standar ini dikelompokkan dalam baku mutu sesuai kelas peruntukannya. 


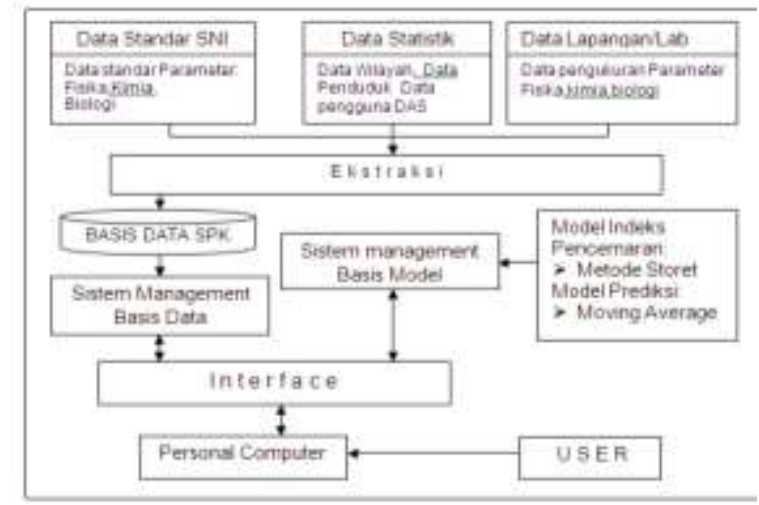

Gambar 2. Diagram Sistem Informasi

2. Data Statistik Perangkat lunak

Pada system pengambilan keputusan ini yang dikategorikan sebagai data statistik adalah: data penduduk disekitar DAS dan data pengguna DAS.

3. Data Pengukuran

Pada system pengambilan keputusan ini yang dikategorikan sebagai data lapangan adalah:

- Data Parameter Fisika (TSS,TDS)
- Data Parameter Biologi (BOD,COD,dll)

- Data Parameter Kimia (konsentrasi unsur - unsur kimia)

\section{Data Ekstraksi}

Data ekstraksi adalah data yang diperoleh dari data penggabungan ketiga data standar, data statistic dan data pengukuran. Proses data ekstraksi ini akan menghasilkan database system pendukung keputusan.

5. Pemodelan Fungsional

a. Diagram Konteks

Diagram konteks perangkat Lunak pendukung keputusan analisis pengelolaan dan pengendalian pencemaran air sungai terlihat pada gambar 3. Terlihat ada dua entitas luar yang berhubungan dengan system yang akan dibangun yaitu Pemerintah sebagai regulator yang mana arus data dari pemerintah yang masuk ke system adalah standart-standart parameter pengukuran kualitas air. Disisi lain lembaga penelitian sebagai lembaga pelaksana penelitian melakukan pemantauan, dan pengukuran dilapangan, sehingga arus data yang berasal dari lembaga peneliti masuk ke system adalah data pengukuran lapangan. Sebagai hasil keluaran yang akan diperoleh dari sistim ini adalah laporan kualitas dan pengendalian pencemaran air sungai (Zachman, 2004).

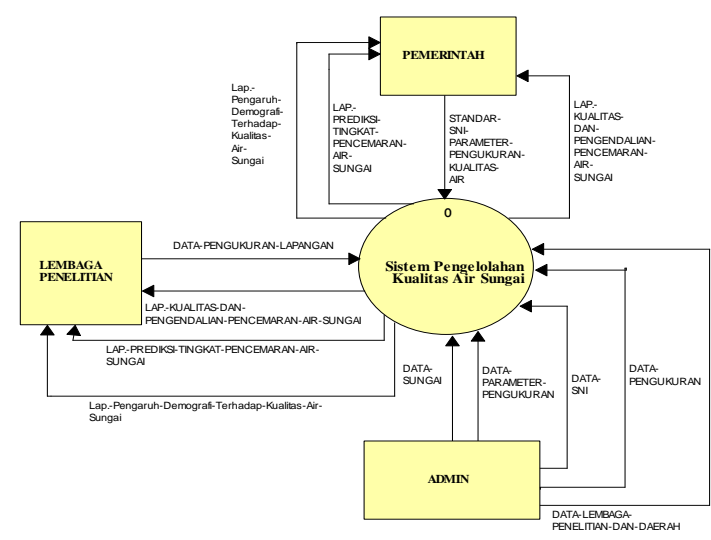

Gambar 3. Diagram Konteks Perangkat Lunak

b. Diagram Arus Data

Diagram arus data menggambarkan bagaimana proses aliran data berjalan dalam sistem, proses aliran data dalam sistim ini digambarkan sebagai berikut:

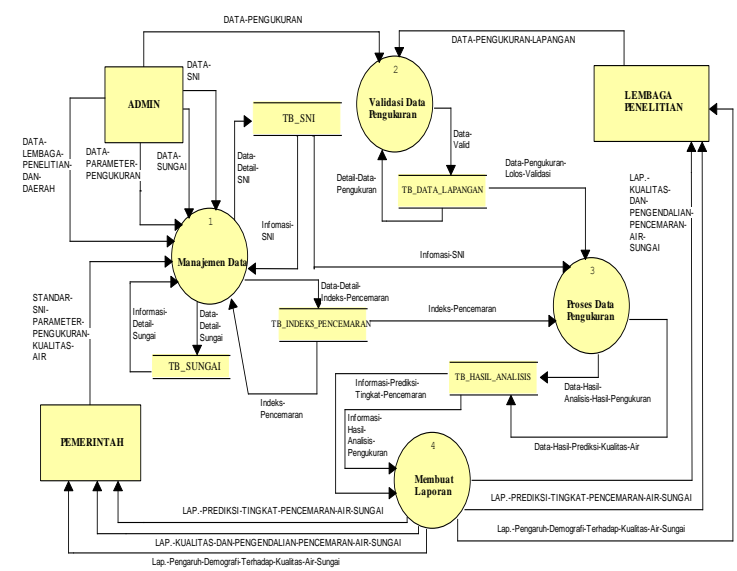

Gambar 4. Diagram Arus Data

\section{c. Diagram ERD}

Selain diagram arus data, juga akan di gambarkan bagaimana hubungan entitas yang terjadi didalam sistim, yang mana hubungan entitas (ERD) wilayah pengelolaan kualitas dan pengendalian pencemaran air sungai adalah seperti pada gambar 5 . 


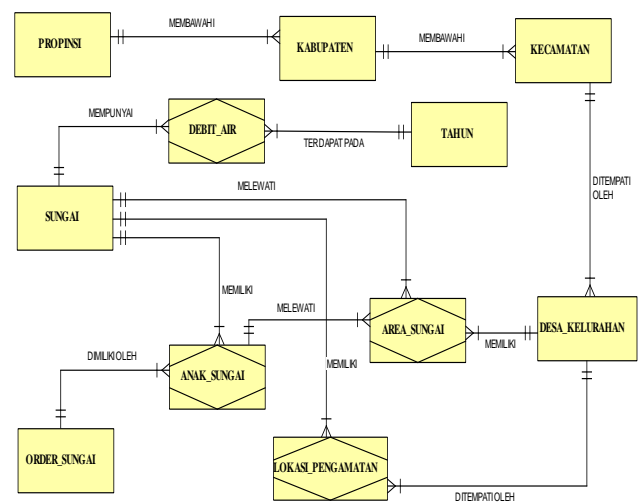

Gambar 5. Diagram Hubungan Entitas

\section{Arsitektur Sistem}

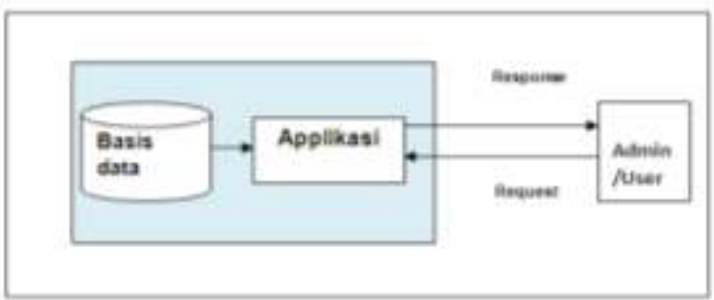

Gambar 6. Arsitektur Sistim

Arsitektur sistim dapat digambarkan sebagai berikut:

a. Basis Data sebagai database berfungsi untuk menampung data ektraksi.Basis data dibangun menggunakan software MySQL.dan MySQL Front.

b. Applikasi Perangkat Lunak Pendukung Keputusan Analisis pengelolaan kualitas dan pengendalian pencemaran air sungai dibangun dengan menggunakan software Delphy.

\section{Pengujian Sistim}

Langkah atau tahapan yang harus dilakukan ketika melakukan pengujian antara lain : 1) Menentukan apa yang akan diketahui melalui pengujian; 2) Menentukan bagaimana pengujian akan dilaksanakan; 3) Membangun kasus uji (test case), yaitu sekumpulan data atau situasi yang akan digunakan dalam pengujian; 4) Menentukan hasil yang diharapkan atau hasil yang sebenarnya; 5) Menjalankan kasus pengujian; dan 6) Membandingkan hasil pengujian dan hasil yang diharapkan.

\section{Tampilan Form Analisis}

Antarmuka ini berfungsi sebagai analisis data pengukuran yang terdiri dari data ukur dan data standart dan wilayah.

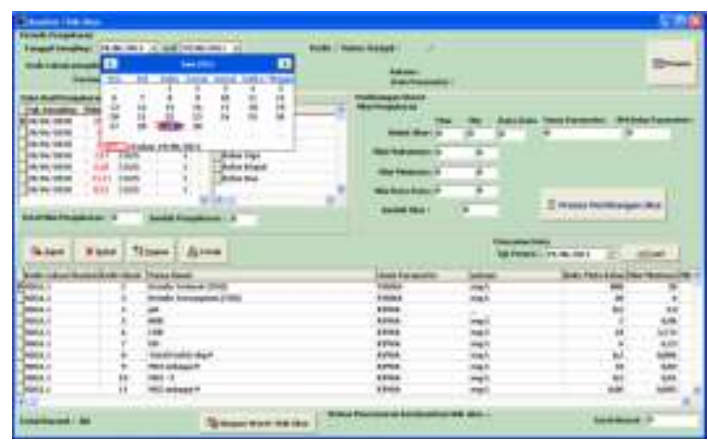

Gambar 7. Tampilan antarmuka analisis data

\section{Tampilan Form Analisis sungai}

Antarmuka ini berfungsi untuk melakukan analisis storet untuk mengetahui status pencemaran sungai.

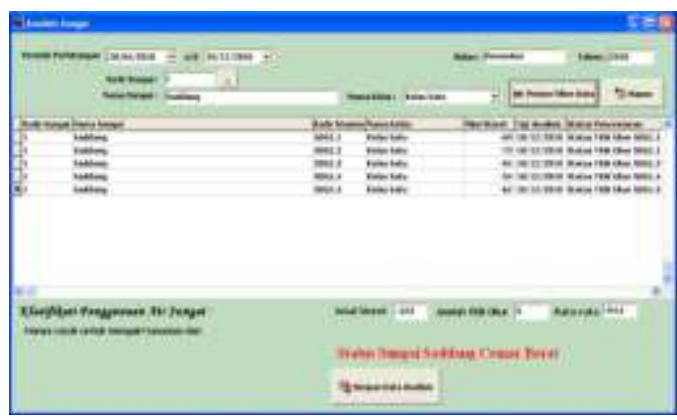

Gambar 8. Tampilan antarmuka analisis sungai

\section{Tampilan Form Analisis Prediksi}

Antarmuka ini berfungsi sebagai analisis prediksi status pencemaran berdasarkan perubahan nilai storet.

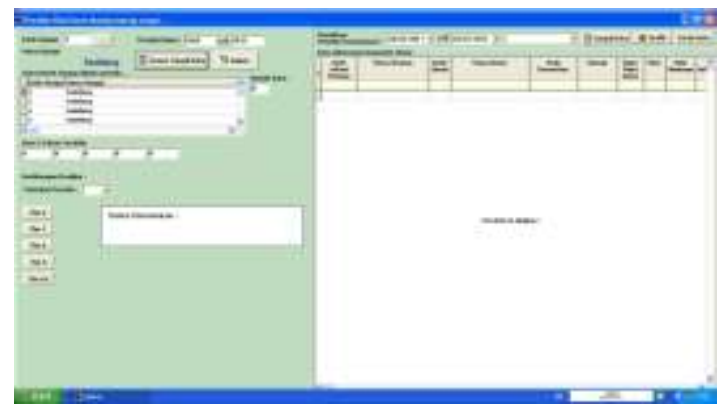

Gambar 9. Tampilan antarmuka analisis prediksi

\section{Hasil Implementasi Sistim}

Hasil implementasi dalam bentuk laporan analisis seperti pada gambar 10 . 


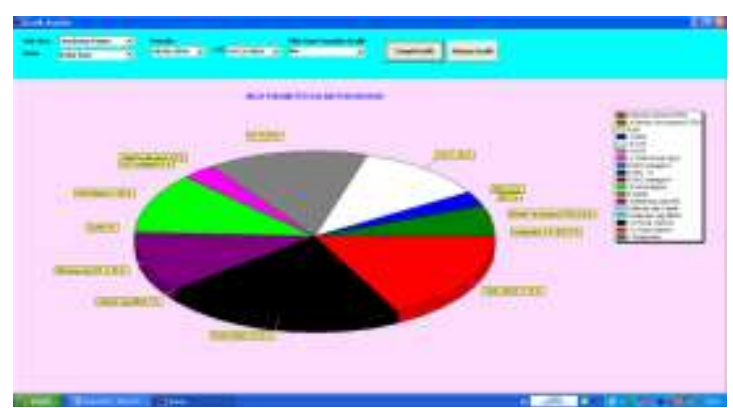

Gambar 10. Tampilan Grafik Hasil analisis data

Pada gambar 10 ditampilkan grafik hasil analisis pada titik ukur pertama. Pada gambar terlihat Perangkat lunak mampu menampilkan hasil analsis dengan beberapa parameter dan klas tertentu.

Tampilan hasil analisis prediksi seperti pada gambar berikut 11 .

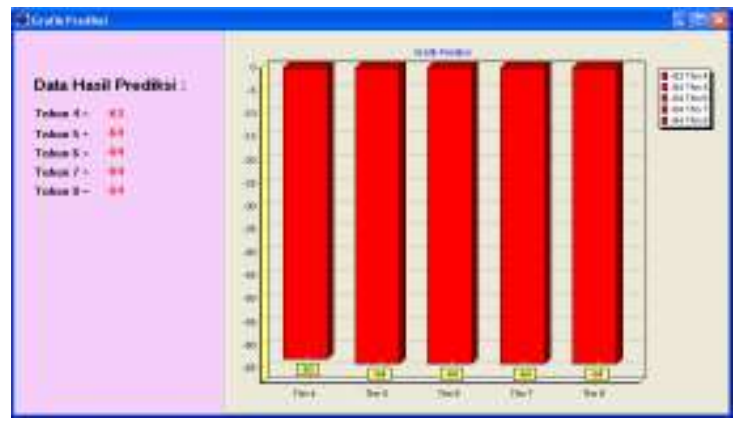

Gambar 11. Tampilan Grafik Hasil Prediksi

Pada gambar 11 terlihat prediksi nilai storet untuk periode peramalan dari tahun 2011 sampai dengan 2014.

\section{KESIMPULAN}

Berdasarkan Hasil penelitian yang telah dilakukan, maka dapat disimpulkan sebagai berikut:

1. Sesuai dengan pengujian dan implementasi yang telah dilakukan dengan mengolah data hasil pemantauan Badan Lingkungan hidup Daerah (BLHD) sulawesi Selatan, maka perangkat lunak ini dapat digunakan sebagai alat bantu monitoring dan analisis pengelolaaan kualitas dan pengendalian pencemaran air sungai.

2. Perangkat lunak analisis pengelolaan kualitas dan pengendalian air sungai dapat melakukan analisis kualitas air sungai dengan menggunakan standar kelas satu sampai kelas empat.

3. Perangkat lunak pendukung keputusan analisis pengelolaan dan pengendalian pencemaran air sungai dapat digunakan untuk memprediksi status pencemaran sungai.

\section{DAFTAR PUSTAKA}

Anonim. 2009. 2009. Indeks Kualitas Lingkungan Hidup. Deputi MENLH Bidang Pembinaan Sarana Teknis dan Peningkatan Kapasitas, Kementrian Lingkungan Hidup (KLH).

Pressman R. 1997. Rekayasa Perangkat Lunak Pendekatan Praktisi (buku satu). Mc Graw Hill Book Co. diterjemahkan oleh Penerbit Andi Offset.

Sommerville, IAN. 2003. Software Engineering (Rekayasa Perangkat Lunak) edisi 6 jilid 1. Erlangga, Jakarta.

Turban, E. 1995. Decision support and Expert system Management Support system, $4^{\text {th }}$ edition. PrenticeHall,Inc,United States of America.

Upper, SRNJ. 2001. Decision Support Systems and Intelligent Systems $6^{\text {th }}$ edition. Prentice Hall.

Walpole ER dan M.H. Raymond. 1995. Ilmu peluang untuk insinyur dan Ilmuwan. Penerbit ITB Bandung.

Zachman. 2004. Visible Analysist Tutorial A Model Driven Approach to Enterprice Architecture Planning, Analysis, Desing and Development, Visible System Corporation 201 spring Street Lexington. 